\title{
PRIMARY WOUND CARE AND EXTERNAL SKELETAL FIXATION IN SURGICAL TREATMENT OF OPEN TIBIAL FRACTURES
}

\author{
Ivana Golubović ${ }^{1}$, Predrag Stojiljković1, ${ }^{1}$, Ivan Golubović ${ }^{2}$, Zoran Radovanović ${ }^{1,4}$, \\ Milan Radojković1,5, Aleksandar Mitić1 ${ }^{1}$ Zoran Baščarević3 , Katarina Kutlešić2, \\ Andrija Krstić ${ }^{1}$, Stevo Najman ${ }^{1}$, Zoran Golubović ${ }^{1,2}$
}

\begin{abstract}
Open tibial fractures are the most severe orthopaedic injuries. The lower leg is often injured due to its position in the locomotor system. The injuries of the lower leg skin and soft tissues, bone comminution and threatening infections make the treatment of these fractures particularly complex. The management of open tibial fractures is potentially associated with numerous complications.

The data on treatment outcomes of 36 patients operatively treated for the open tibial fractures in Clinic for Orthopaedic surgery and traumatology, Clinical Center Nis in Serbia during the period from January 1, 2012 to June 31, 2014 were retrospectively analyzed and compared. In all the patients, after thorough wound rinsing, removal of the foreign bodies, debridement and delayed wound closure, fractured bone segments were repositioned and stabilized using external fixator.

In $28(77.78 \%)$ patients fractures healed without major complications, while in 8 (22.22\%) major complications occurred, including tibial osteomyelitis in $3(8.33 \%)$ and fracture malunion in $5(13.88 \%)$ patients.

Primary wound care, external fixation, antibiotic and antitetanus prophylaxis are crucial in treatment of open tibial fracture.

Acta Medica Medianae 2018;57(4):22-28.
\end{abstract}

Key words: Open tibial fractures, primary wound care, external skeletal fixation

\footnotetext{
${ }^{1}$ University of Niš, Faculty of Medicine, Serbia

${ }^{2}$ Clinic for Orthopaedic Surgery and Traumatology, Clinical center Niš, Serbia

'Institute for Orthopaedic Surgery 'Banjica', Belgrade, Serbia

${ }^{4}$ Radiology Center, Clinical Center Niš, Niš, Serbia

${ }^{5}$ Surgery Clinic, Clinical Center Niš, Niš, Serbia
}

Contact: Zoran Golubović

Gutenbergova 37, 18000 Niš, Serbia

E-mail: doktorzorangolubovic@gmail.com

\section{Introduction}

Open tibial fractures are the most severe orthopaedic injuries. The lower leg is often injured due to its position in the locomotor system. Tibial diaphysis fractures are the most common of all long bone diaphyseal fractures in $40 \%$, while the open tibial fractures are the most common open bone fractures (1). Open tibial fractures are closed in 77 $\%$ and open in $33 \%$ (2). Open tibial fracture occurs in approximately two per 10000 persons per year in the developed country (3). Open lower leg fractures most commonly occur in traffic accidents and during agricultural and sport activities (1). The injuries of the lower leg skin and soft tissues, bone comminution and threatening infections make the treatment of these fractures particularly complex. The treatment includes thorough wound rinsing, removal of foreign bodies, debridement, bone segments reposition, external fixation or internal fixation, antibiotic therapy and antitetanus prophylaxis (4).

The management of open lower leg fractures is potentially associated with numerous complications including: soft tissue infection, osteomyelitis, fracture malunion/nonunion and the loss of the extremity (5). The management success depends on both the severity of injury, patient's general condition and comorbidities and treatment modality applied.

\section{The aim of the study}

The aim of our study was to present the results of the open lower leg fracture treatment with primary wound closure, external fixation, antibiotic and antitetanus prophylaxis.

\section{Materials and methods}

The data on treatment outcomes of 36 patients operatively treated for the open tibial fractures 
in Clinic for Orthopaedic surgery and traumatology, Clinical Center Nis in Serbia during the period from January 1, 2012 to June 31, 2014 were retrospectively analyzed and compared.
There were $27(75 \%)$ men and $9(25 \%)$ women, most of which being in the third $8(22.22 \%)$, fifth $7(19.44 \%)$ and sixth $8(22.22 \%)$ decade of life (Graph 1).

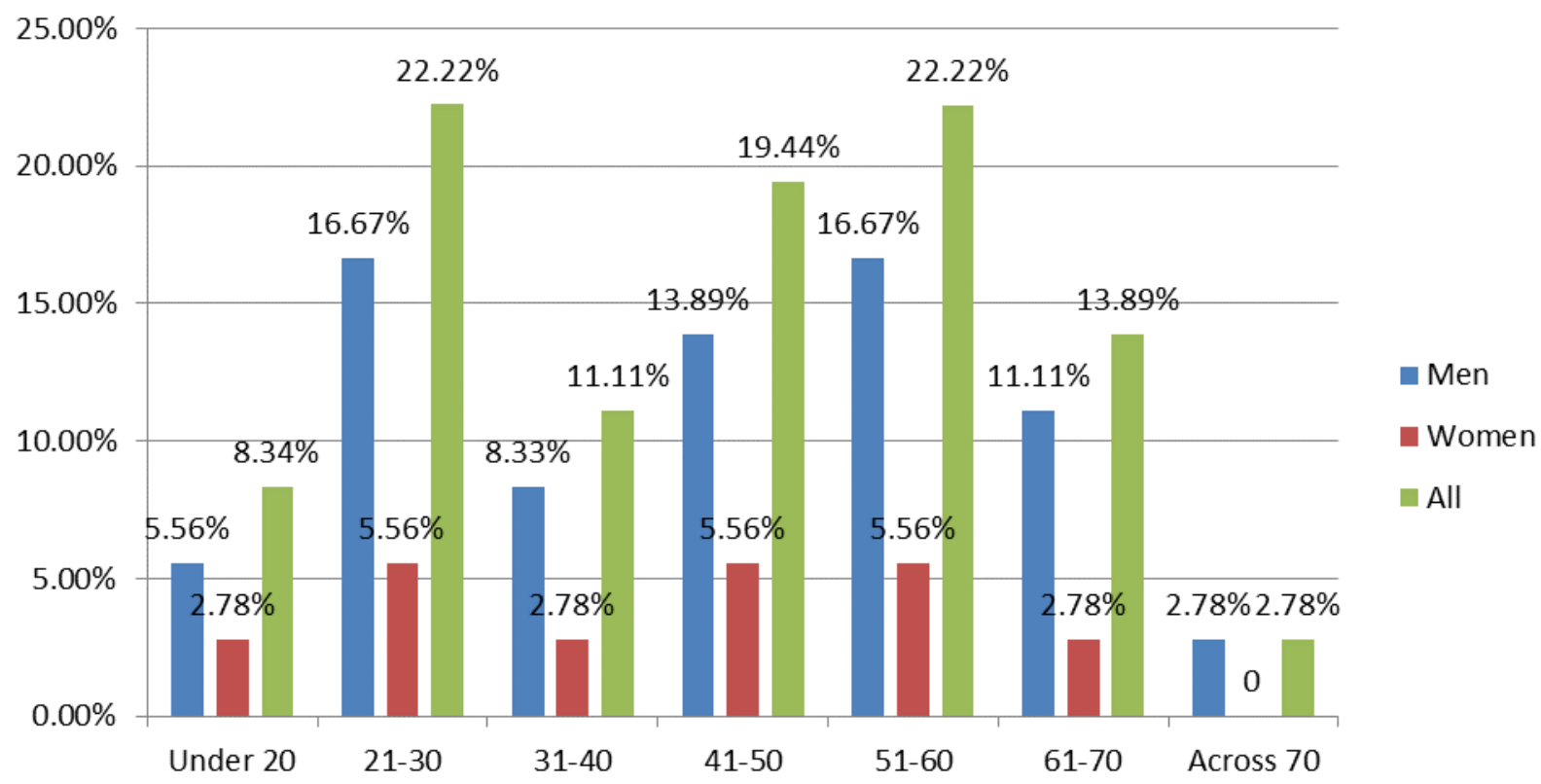

Graph 1. Gender and age distribution of the patients

Most of the patients were injured in the traffic accidents $21(58 \%)$, while $8(22 \%)$ of them were injured during the agricultural activities. The downfall while walking caused the injury in $6(17 \%)$ pati-ents and $1(3 \%)$ was injured by a firearm missile (Graph 2).

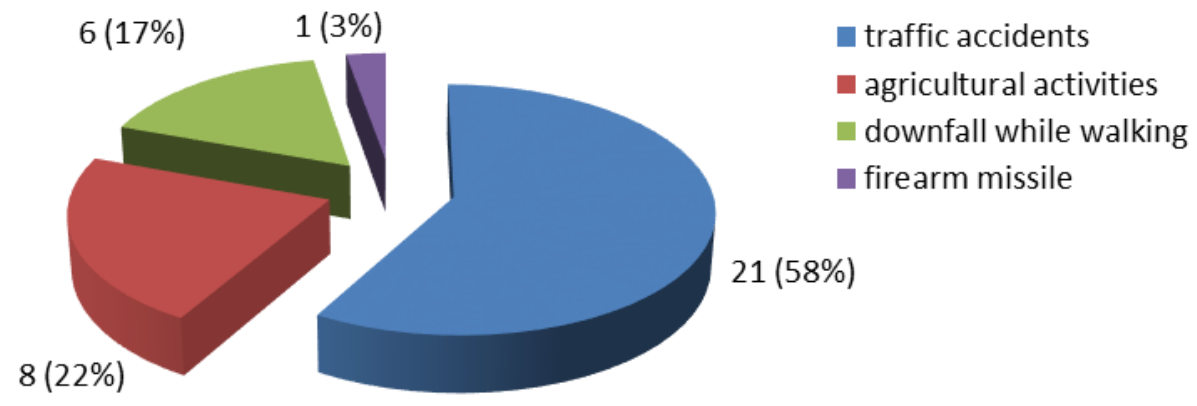

Graph 2. The mechanisms of injury

For the analysis we used the open fracture classification system established by Ramon Gustilo (6) according to which there were 9 (25\%) patients with grade I, $7(19 \%)$ with grade II, $11(31 \%)$ with grade IIIA, $8(22 \%)$ with grade IIIB and one $(3 \%)$ with grade IIIC open lower leg fracture (Graph 3).

In all the patients, after thorough wound rinsing, removal of the foreign bodies, debridement and delayed wound closure, fractured bone segments were repositioned and stabilized using Mitkovic external fixator.

Immediately upon admission, all patients were administered antimicrobial therapy that included the combination of a third-generation cephalosporin (ceftriaxone, 2gr/24h) and semi-synthetic aminoglycoside (amikacin, $1 \mathrm{gr} / 24 \mathrm{~h}$ ). 


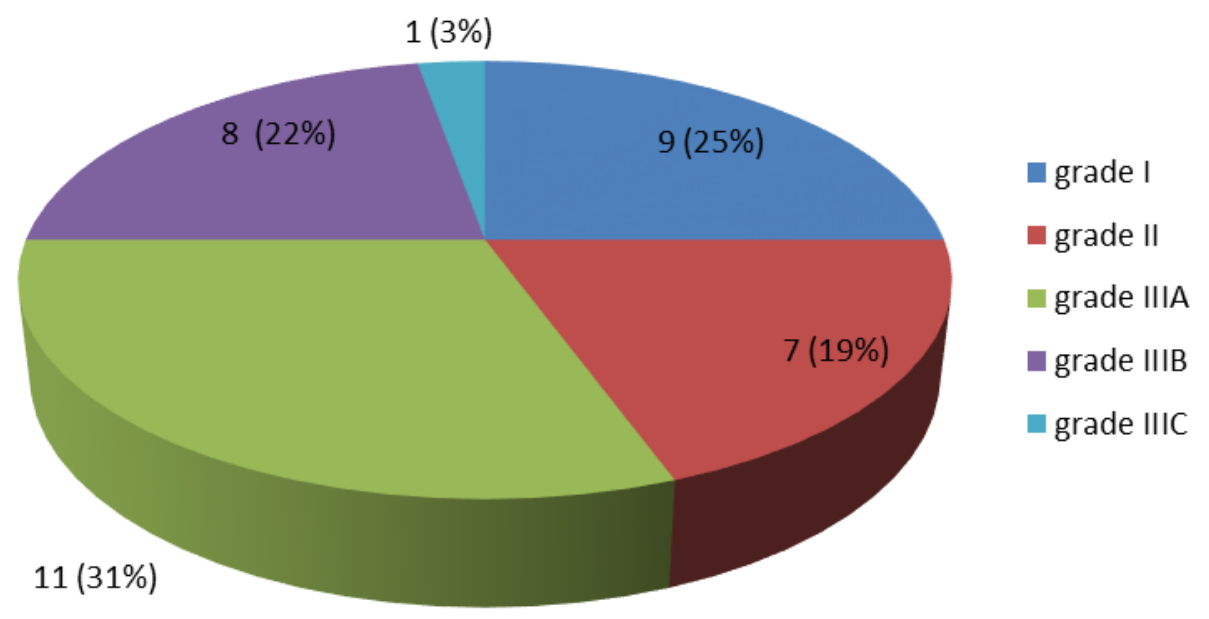

Graph 3. The severity of injuries of our patients according to the Gustilo open fracture classification

Extremely contaminated wounds, for example with soil, with increased risk of clostridial infection and gas gangrene, required the administration of additional antibiotic (penicillin G sodium, 4 to 6 million units/day or clindamycin). All patients received antitetanus prophylaxis according to the protocol.

\section{Results}

In $28(77.78 \%)$ patients fractures healed without major complications (Figure 1), while in 8 (22.22\%) major complications occurred including tibial osteomyelitis in $3(8.33 \%)$ and fracture malunion in $5(13.88 \%)$ patients (Graph 4$)$. Minor complications such as soft tissue infection, surrounding the pins of external fixator and soft tissue infection were detected in $6(16.67 \%)$ and $4(11.11 \%)$ patients, respectively.

Infection of the soft tissue surrounding the pins and soft tissue infection were successfully treated with thorough daily debridement and wound care and antimicrobial medication according to the antibiogram results. Tibial osteomyelitis developed in one patient with grade IIIA and 2 patients with grade IIIB open fractures. Fracture malunion and pseudoarthrosis occurred in one patient with grade II, 2 patients with grade IIIA and 2 patients with grade IIIB fractures. In 2 (5.56\%) patients primary bone comminution caused nonunion, while in $3(8.33 \%)$ patients open fractures resulted in tibial hypertrophic pseudoarthrosis.

\section{Discussion}

Open lower leg fractures most commonly occur in traffic accidents, with the direct mechanism of injury. The indirect mechanism of injury implies the rupture of lower leg soft tissue and skin from the inside with sharp segment(s) of fractured bone(s) resulting in open fracture. Indirect mechanism often causes less severe injuries compared to the direct mechanism (1).
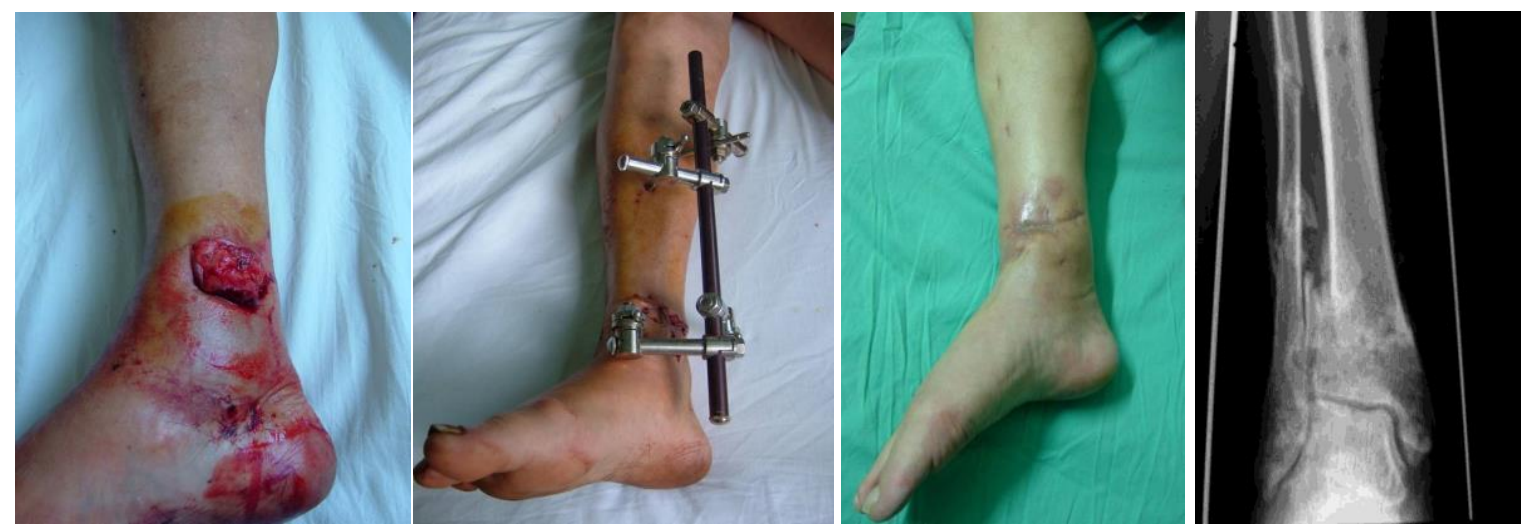

Figure 1. Open tibial fracture treated with external fixator Mitkovic 


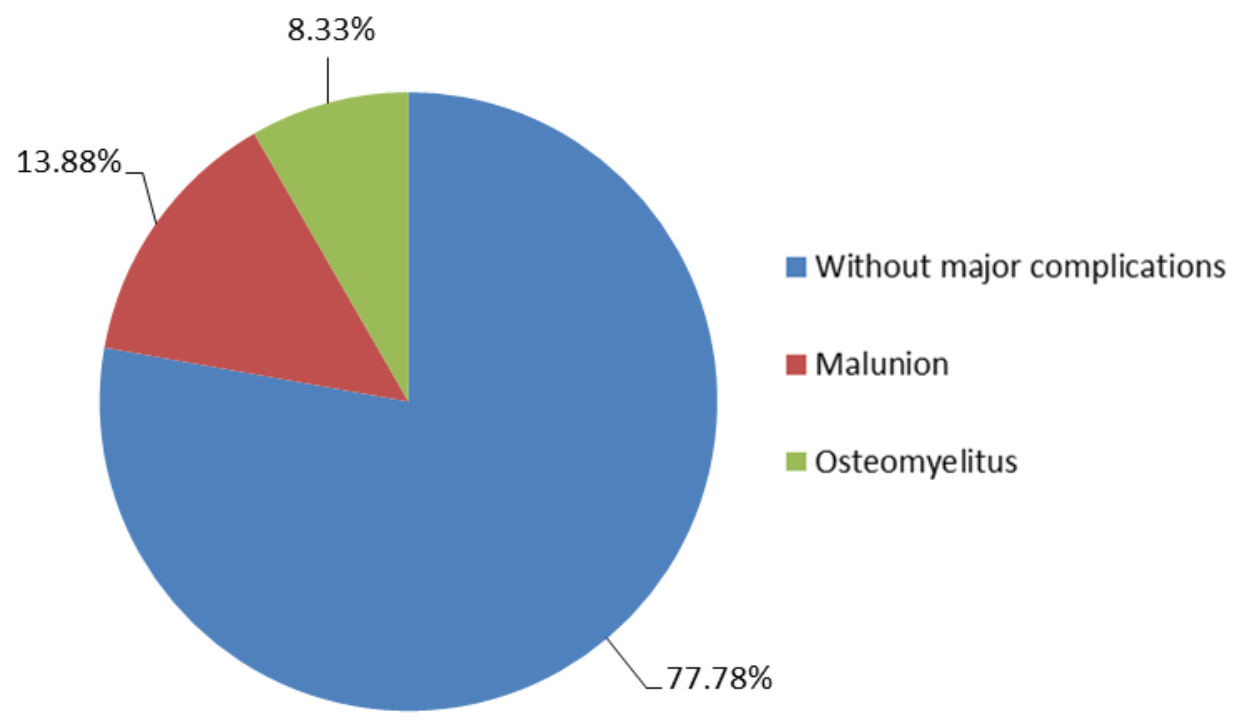

Graph 4. Open tibial fracture treatment results

All open fractures are considered primarily contaminated. Among numerous classifications the most commonly used is the one proposed by Ramon Gustilo based on the strength of the force that caused the lower leg bone fracture and soft tissue damage (6).

Lower leg open fractures require urgent surgical treatment in case of satisfactory general condition of the patient. The "6-hour rule", long-accepted guideline for dealing with open fractures, stating that, to prevent infection, open fractures should be fully managed within a 6-hour time frame, should be applied as its relevance is supported by the evidence provided by Kindsfater and Jonassen (7) and Kreder and Armstrong (8) in 1995.

Early parenteral antibiotic administration is associated with the infection incidence decrease and should be applied immediately upon admission. Antibiotic treatment is to be administered during 48 to 76 hours in patients with grade I and II and up to 120 hours in patients with grade III open fractures (9).

Primary wound care is essential for the prevention of osteomyelitis, gas gangrene and tetanus. Before detailed debridement, thorough wound rinsing using saline and hydrogen and removal of foreign bodies, including the parts of soil and clothing and bone fragments, should be done. Sometimes, more than $10 \mathrm{~L}$ of liquid are required for quality wound rinsing. It includes the removal of damaged skin, subcutaneous fat, fascia, and muscles, as well as removal of small periosteum bone fragments. $\mathrm{Ne}-$ crotic muscle tissue is a good host for both anaerobic and aerobic bacteria. When assessing the muscle vitality, its colour, consistency, bleeding and contractility should be taken into consideration (1).

Widely accepted surgical treatment of the Gustilo-Anderson types IIIB and IIIC open fractures these days is a routine treatment involving the use of external fixation $(10,11)$.
External fixation is a standard method of all lower leg fracture stabilization. It provides good biomechanical conditions for fracture healing, allows good approach for wound care and it does not interfere with the knee and ankle movements. Problems associated with this fixation method include frequent soft tissue and bone infections around the pins when the fixator is applied longer than 6 months and higher incidence of fracture malunion and nonunion (12).

Satisfactory clinical function has been achieved with external fixation at the $89 \%$ of the patients with open tibial fractures Grade III with $93 \%$ of the fractures healing well and as expected, which was noted in a study case conducted by Edward in 1988 (13).

Intramedullary nailing in the therapy of Grade IIIB and IIIC fractures was leading to infection in $20.3 \%$ of the cases and therefore was proclaimed the risky treatment by Yokoyama $\mathrm{K}$ (14).

Moreover the conclusion is that using secondary nailing after delayed primary one or primary external fixator is increases the risk of infection (15).

Fracture management with intramedular nailing and external fixation was compared through several clinical trials; both ways were applied to treat the open tibial shaft fractures. The selection of the treatment depended both on surgical experience of the doctor as well as on patient presentation. Advantages of external fixation treatment are shorter time and its suitability in polytrauma patients, but on the other hand it has many disadvantages such as high incidence of complications like refracture, nonunion or delayed union and not always being well tolerated by the patients. While on the other side, intramedullary nailing includes less time for healing, earlier load-bearing and extremely low risk of complications (15-17). 
Osteosynthesis with plate should be avoided in treatment of open tibial fractures due to high risk of infection (18).

Open fracture wound should not be primary closed, but left open and closed using secondary sutures or some of the plastic surgery techniques (depending on the severity of the soft tissue damage/defect such as fasciocutaneous flap, microvascular transplantation etc.) when certain that no infection occurred (1). Closing the wound as early as possible, according to contemporary orthopaedic principles, requires previous thorough debridement and absence of contamination. Caudle and Stern reported that early aggressive soft tissue reconstru ction during the first 7 days after the injury, in order to cover the fractured bone segments in patients with grade III open fractures, significantly reduces the risk of infection, fracture malunion/nonunion and amputation (19).

\section{Conclusion}

Primary wound care, external fixation, antibiotic and antitetanus prophylaxis, delayed wound closure are crucial in treatment of open tibial fracture. Most common complications of open tibial fracture are deep bone infection - osteomyelitis and fracture malunion or nonunion.

\section{Acknowledgment}

This work is part of the project "Virtual human osteoarticular system and its application in preclinical and clinical practise" (No. III 41017), supported bywas funded by the Ministry of Edu-cation, Science and Technological Development of Serbia.
1. Golubović $Z$, Stojiljković $P$, Mačukanović-Golubović $L$, Milić D, Milenković S, Kadija M, et al. External fixation in the treatment of open tibial shaft fractures. Vojnosanitet Pregl 2008; 65(5):343-7. [CrossRef] [PubMed]

2. Court-Brown CM, McBirnie J. The epidemiology of tibial fractures. J Bone Joint Surg 1995; 77B:417-21. [CrossRef] [PubMed]

3. Court-Brown CM, Bugler KE, Clement ND, Duckworth $A D$, McQueen MM. The epidemiology of open fractures in adults: a 15-year review. Injury 2012; 43:891-7. [CrossRef] [PubMed]

4. Cross WW, Swiontkowski MF. Treatment principles in the management of open fractures. Indian J Orthop 2008; 42(4):377-86. [CrossRef] [PubMed]

5. Kohlprath R, Assal M, Uc, kay I, Holzer N, Hoffmeier P, Suva D. Open fractures of the tibia in the adult: surgical treatment and complications. Rev Med Suisse 2011; 7(322):2482-4. [PubMed]
6. Gustilo RB, Mendoza RM, Williams DN. Problems in the management of type III (severe) open fractures. A new classification of type III open fractures. J Trauma 1984; 24:742-6. [CrossRef] [PubMed]

7. Kindsfater $\mathrm{K}$, Jonassen EA. Osteomyelitis in grade II and III open tibia fractures with late debridement. J Orthop Trauma 1995; 9(2):121-7.

[CrossRef] [PubMed]

8. Kreder $\mathrm{HJ}$, Armstrong P. A review of open tibia fractures in children. J Pediatr Orthop 1995; 15(4): 482-8. [CrossRef] [PubMed]

9. Golubovic I, Vukasinovic Z, Stojiljkovic P, Golubovic Z, Stamenic S, Najman S. Open segmental fractures of the tibia treated by external fixation. Srp Arh Celok Lek 2012; 140(11-12):732-7. [CrossRef] [PubMed]

10. McKee MD, Yoo DJ, Zdero R, Dupere M, Wild L, Schemitsch $\mathrm{EH}$, et al. Combined single-stage osseous and soft tissue reconstruction of the tibia with the 
Ilizarov method and tissue transfer. J Orthop Trauma 2008; 22(3):183-9. [CrossRef] [PubMed]

11. Kataria H, Sharma N, Kanojia RK. Small wire external fixation for high-energy tibial plateau fractures. J Orthop Surg 2007; 15(2):137-43. [CrossRef] [PubMed]

12. Mitković $M$, Bumbaširević $M$, Golubović $Z$, Mićić $I$, Mladenović D, Milenković $S$, et al. New concept in external fixation. Acta Chir Iugosl 2005; 52(2): 107-11. [CrossRef] [PubMed]

13. Edwards CC, Simmons SC, Browner BD, Weigel MC. Severe open tibial fractures. Results treating 202 injuries with external fixation. Clin Orthop Relat Res 1988; 230:98-115. [PubMed]

14. Yokoyama $K$, Itoman $M$, Uchino $M$, Fukushima $K$, Nitta $\mathrm{H}$, Kojima $\mathrm{Y}$. Immediate versus delayed intramedullary nailing for open fractures of the tibial shaft: a multivariate analysis of factors affecting deep infection and fracture healing. Indian J Orthop 2008; 42(4): 410-9. [CrossRef] [PubMed]
15. Blachut PA, Meek RN, O'Brien PJ. External fixation and delayed intramedullary nailing of open fractures of the tibial shaft. J Bone Joint Surg Am 1990; 72(5):72935. [CrossRef] [PubMed]

16. Koval KJ, Clapper MF, Brumback RJ, Stribling Ellison $P$, Poka $\mathrm{A}$, Bathon $\mathrm{H}$, et al. Complication of reamed intramedullary nailing of the tibia. J Orthop Trauma 1991; 5:184-9. [CrossRef] [PubMed]

17. Court-Brown CM, Keating JF, McQueen MM. Infection after intramedullary nailing of the tibia. J Bone J Surg 1992; 74(B):770-4. [PubMed]

18. Melvin JS, Domrizikabroski DG, Torbert JT, Kovach SJ, Esterhai JL, Mehta S. Open tibial shaft fractures: II. Definitive management and limb salvage. J Am Acad Orthop Surg 2010; 18:108-17. [CrossRef] [PubMed]

19. Caudle RJ, Stern PJ. Severe open fractures of the tibia. J Bone Joint Surg Am 1987; 69(6):801-7. [CrossRef] [PubMed] 


\title{
PRIMARNA OBRADA RANE I SPOLJNA SKELETNA FIKSACIJA U LEČENJU OTVORENIH PRELOMA TIBIJE
}

\author{
Ivana Golubović ${ }^{1}$, Predrag Stojiljković1,2, Ivan Golubović2, Zoran Radovanović1,4, \\ Milan Radojković1,5, Aleksandar Mitić ${ }^{1}$, Zoran Baščarević3 , Katarina Kutlešić ${ }^{2}$, \\ Andrija Krstić1, Stevo Najman ${ }^{1}$, Zoran Golubović1,2
}

\author{
${ }^{1}$ Univerzitet u Nišu, Medicinski fakultet, Srbija \\ ${ }^{2}$ Klinika za ortopedsku hirurgiju i traumatologiju, Klinički centar u Nišu, Srbija \\ ${ }^{3}$ Specijalna ortopedska bolnica Banjica, Beograd, srbija \\ ${ }^{4}$ Centar za radiologiju, Klinički centar Niš, Niš, Srbija \\ ${ }^{5}$ Klinika za digestivnu hirurgiju, Klinički centar Niš, Niš, Srbija
}

Kontakt: Zoran Golubović

Gutenbergova 37, 18000 Niš, Srbija

E-mail: doktorzorangolubovic@gmail.com

Otvoreni prelomi tibije spadaju u najteže ortopedske povrede. Zbog svog položaja u lokomotornom sistemu, potkolenica se često povređuje. Povrede kože i mekog tkiva potkolenice, kominukacija kosti i prateće infekcije čine lečenje ovih preloma naročito složenim.

Lečenje otvorenih preloma potkolenice je potencijalno povezano sa brojnim komplikacijama. U radu se prikazuju rezultati operativnog lečenja 36 pacijenata sa otvorenim prelomom potkolenice, koji su lečeni u Klinici za ortopediju i traumatologiju Kliničkog centara u Nišu u periodu od 1. januara 2012. do 31. juna 2014. godine. Kod svih pacijenata, nakon primarne obrade rane, odstranjivanja stranih tela, debridmana i odloženog zatvaranja rane, polomljeni koštani fragmenti su reponirani i stabilizovani korišćenjem spoljašnjeg skeletnog fiksatora.

Kod 28 pacijenata $(77,78 \%)$ prelom je zarastao bez većih komplikacija, dok je kod 8 $(22,22 \%)$ pacijenata došlo do većih komplikacija, uključujući osteomijelitis tibije kod tri $(8,33 \%)$ i nezarastanje preloma kod $5(13,88 \%)$ pacijenata.

Primarna obrada rane, spoljna skeletna fiksacija, antibiotska i antitetanusna profilaksa su ključni u lečenju otvorenih preloma tibije.

Acta Medica Medianae 2018;57(4):22-28. fiksacija

Ključne reči: otvoreni prelomi potkolenice, primarna obrada rane, spoljna skeletna 